\title{
Chrysymenia tigillis sp. nov. (Rhodymeniales, Rhodophyta) from the Sultanate of Oman, with a census of currently recognized species in the genus Chrysymenia
}

\author{
Michael J. Wynne \\ Department of Ecology and Evolutionary Biology and Herbarium, University of Michigan, Ann Arbor, Michigan 48109, USA
}

\section{SUMMARY}

Chrysymenia tigillis sp. nov. is described on the basis of a few specimens collected from Dhofar, Sultanate of Oman. The new species is known only from southern Oman, a region of the northern Arabian Sea that is strongly impacted by the upwelling from the summertime monsoon. It is distinguished from other species of the genus by the simple nature of the blades, their dimensions (to $75 \mathrm{~cm}$ in length and to $21 \mathrm{~cm}$ in width), the rough, bumpy surface of the blades, and the presence of internal struts connecting the inner sides of the blades. A census of the currently recognized species in the genus Chrysymenia is provided.

Key words: Chrysymenia, Chrysymenia tigillis, marine algae, new species, Omani flora, red algae.

\section{INTRODUCTION}

In recent years the benthic marine algal flora of the Sultanate of Oman, northern Arabian Sea, has been receiving greater attention. The publication of several newly described taxa and new records for this region has resulted (Nizamuddin \& Campbell 1995; Wynne 1998, 1999a,b, 2000, 2001a,b, 2002a,b, 2003a,b, 2003c, 2004, 2005; Wynne \& Jupp 1998; Wynne \& Leliaert 2001; Schils \& Coppejans 2002; Wynne \& de Jong 2002; Wynne \& Freshwater 2004).

The Rhodymeniacean genus Chrysymenia is characterized as having erect or repent thalli, terete, compressed, or flattened, entirely hollow and lacking diaphragms or regular constrictions, the cavity with or without medullary filaments, unstalked gland cells usually present on inner cortical/medullary cells, and cystocarps without an enveloping network of filaments. The consistency of the thalli in the various species ranges from soft to firm, and abundant mucilage is present in the hollow interior. The closely related genus Botryocladia differs because its thalli have solid portions (Feldmann 1945; Kylin 1956), whereas the only solid portion of thalli in Chrysymenia is the basal stipe, or region of attachment. Botryocladia also differs by its ramisympodal growth (Kylin 1956; Millar 1990). The genus Irvinea, segregated from Botryocladia by Guiry (in Saunders et al. 1999), also has terete solid axes terminating in sympodially developed hollow vesicles (Brodie \& Guiry 1988, as Botryocladia ardreana Brodie et Guiry). But it possesses distinctive features, such as the arrangement of cortical cells in rosettes, strongly protruding cystocarps, and the formation of gland cells on special initials. Like Botryocladia, its terete axes separate it from Chrysymenia. Hymenocladia, with large foliose blades, is distinctive in the family because of its tetrahedrally divided tetrasporangia and the medulla being composed of intermixed large and small cells (Harvey 1860b, as Rhodymenia polymorpha Harvey; Sparling 1957; Womersley 1996). Cenacrum, a genus also with thalli that are large, foliose, and usually deeply dissected, is separated on the basis that its initially hollow regions become progressively filled with ingrowing rhizoidal filaments such that proximally the interior becomes solidly packed with filaments (Ricker \& Kraft 1979).

The only previously recorded Chrysymenia from Oman is Chrysymenia grandis Okamura (1933) reported by Wynne (2001b), on the basis of numerous collections made from Dhofar. The occurrence of that species from Oman was the first record outside of its then known range in Japan (Yoshida 1998).

\section{MATERIALS AND METHODS}

The specimens were gathered by scuba diving. The several specimens were then pressed as herbarium specimens. Smaller amounts were preserved in 5\% formalin in seawater. Voucher material has been deposited in the Natural History Museum, London (BM), the Herbarium of the University of Michigan $(\mathrm{MICH})$, and the Natural History Museum of Oman, Muscat (ON). Herbarium abbreviations are according to Holmgren et al. (1990).

\footnotetext{
*To whom correspondence should be addressed.

Email: mwynne@umich.edu

Communicating editor: J. A. West.
}

Received 31 January 2005; accepted 25 March 2005. 
For comparison, these other species were examined: Chrysymenia grandis Okamura.

Japan. Off Tsudo, Oki Islands: 3.vii. 1986. leg. $M$. Kajimura no. 726, 40 m, tetrasporic (MICH).

Chrysymenia planifrons (Melvill) J. Agardh.

USA, Florida. Indian River Inlet (now Fort Pierce Inlet) $\left(27.4700^{\circ} \mathrm{N}, 80.2883^{\circ} \mathrm{W}\right)$ : v. 1899 , leg. Mrs G. A. Hall, two cystocarpic specimens, washed ashore (NY). Jupiter Inlet $26.9433^{\circ} \mathrm{N}, 80.0733^{\circ} \mathrm{W}$ : 14.ix. 1896, leg. Mrs G. A. Hall, Phycotheca Boreali-Americana 388 (cystocarpic in MICH; cystocarpic in NY; male in NY).

\section{RESULTS AND OBSERVATIONS}

\section{Chrysymenia tigillis M. J. Wynne sp. nov. (Figs 1-12)}

Aliis speciebus in genere natura simplici laminarum, amplitudine laminarum (tenus $75 \mathrm{~cm}$ in longitudine, tenus $21 \mathrm{~cm}$ in latitudine), pagina grossa atque aspero laminarum, et praesentia tigillorum internorum latores interiores laminarum connexorum. Plantae feminae cystocarpiis super paginam laminae dispersis; plantae masculae et tetrasporangiae ignotae.

\section{Chrysymenia tigillis M. J. Wynne sp. nov. (Figs 1-12)}

It is distinguished from other species of the genus by the simple nature of the blades, their long dimensions (to $75 \mathrm{~cm}$ in length, to $21 \mathrm{~cm}$ in width), the rough and bumpy surface of the blades, and the presence of internal struts connecting the inner sides of the blades. Female plants with cystocarps scattered over blade surfaces; spermatangial and tetrasporangial plants not known.

Etymology: Latin tigillum (s. n. II), strut; abl. pl. tigillis, with struts.

Holotype: Sultanate of Oman. Sadh $\left(17.0437^{\circ} \mathrm{N}\right.$, 55.0805E), east of Mirbat, Dhofar: 22.ix. 2001, leg. Glenn Richards and Henry Ford 22092001-17-03, scuba-collected from a depth of $12 \mathrm{~m}$. Cystocarpic. Deposited in MICH.

Isotypes: Deposited in BM and ON. Both isotypes are also cystocarpic.

Additional collection: 22092001-17-19 (same data as for the type) ( $\mathrm{MICH})$.

\section{Vegetative organization}

The thallus (Fig. 1) is erect, simple, foliose, up to $75 \mathrm{~cm}$ in length and up to $21 \mathrm{~cm}$ in width, with a thickness of approximately $1 \mathrm{~mm}(860-1250 \mu \mathrm{m})$. The blade surface is rough, bumpy, locally corrugated. The texture is slippery, but somewhat firm and succulent.

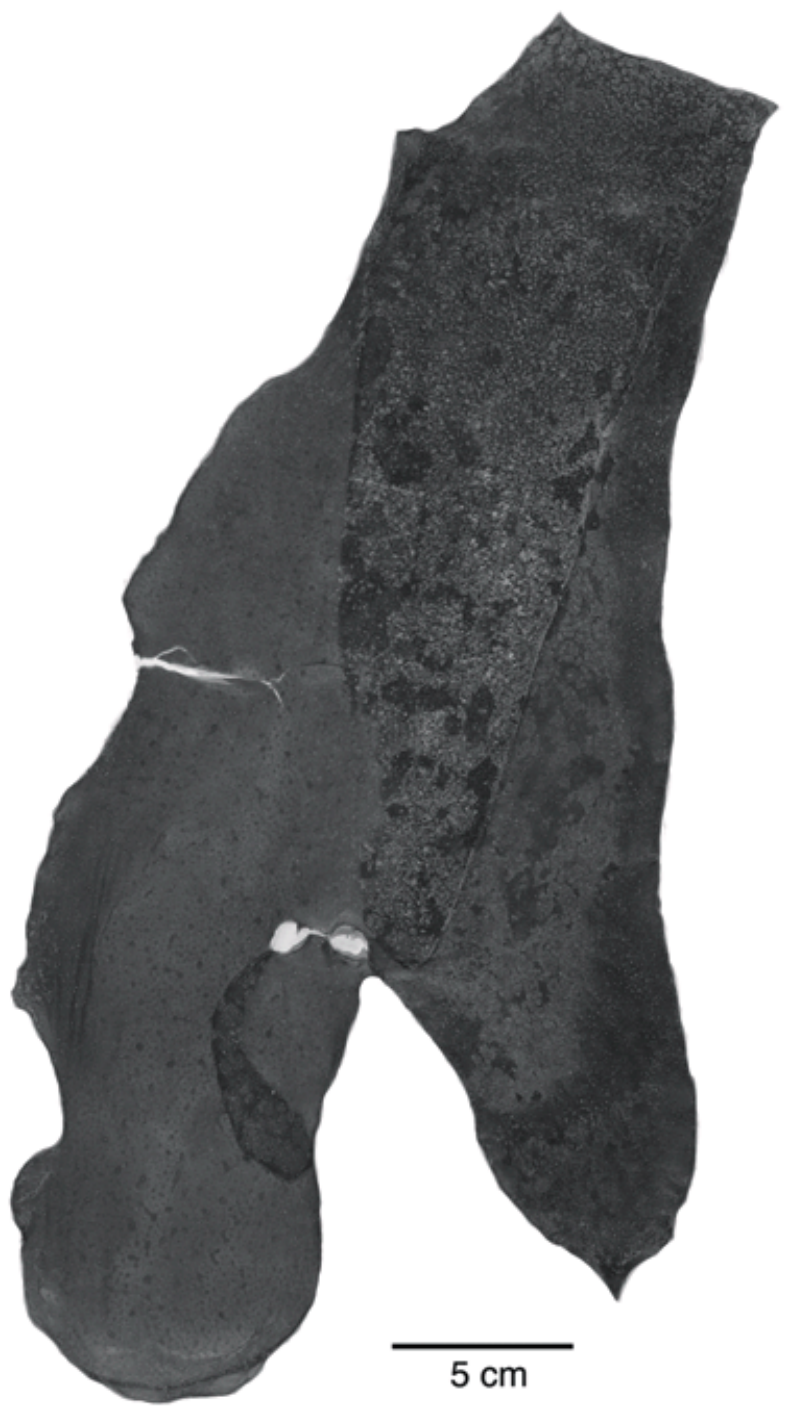

Fig. 1. Chrysymenia tigillis. Holotype specimen. Herbarium of the University of Michigan (MICH).

The color is dull reddish when the specimen is pressed. In one isotype specimen (in BM) a pair of blades share an attachment stipe of $3 \mathrm{~mm}$ in height and $2 \mathrm{~mm}$ in diameter. The larger blade of the pair then has a stipe of $6 \mathrm{~mm}$ before abruptly expanding into the lamina. The blade is essentially hollow and filled with mucilage, but transversely oriented struts are present (Figs 2,3). These struts are composed of branched chains of variously sized cells that connect the inner surfaces of the blade. Inner polygonal subcortical cells cut off chains of cylindrical cells inwardly, and they form branching chains of cells that extend in various directions, connecting with cells on the opposite inner face of the hollow medulla. Each strut is composed of a plexus of 3-D branched chains of cells of various sizes (spherical and elongate). The struts are not continuous diaphragms, but are sporadic discrete columns. The cortex 
2

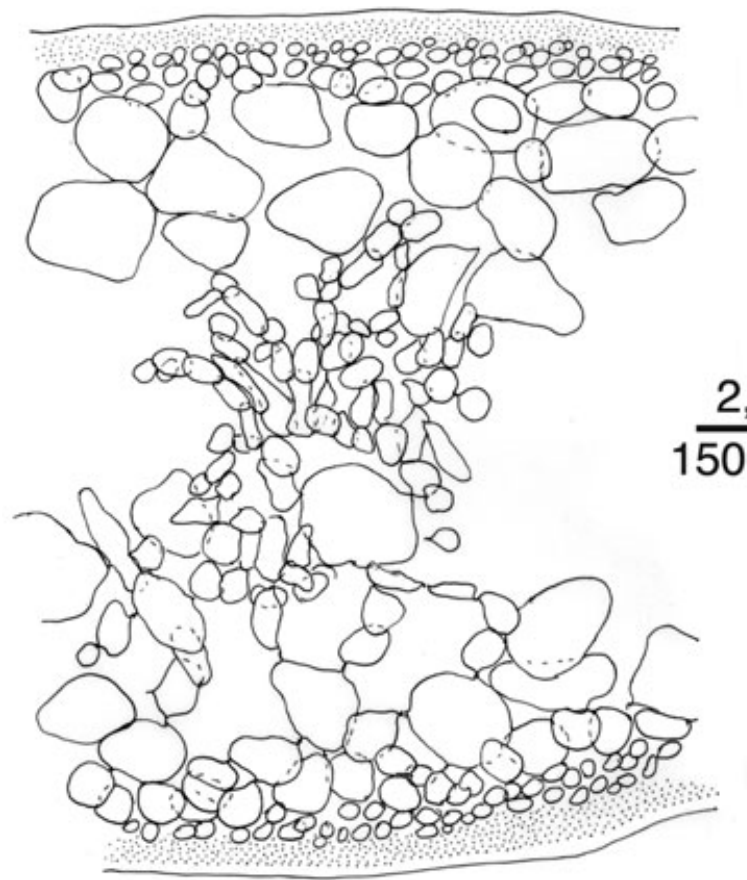

3

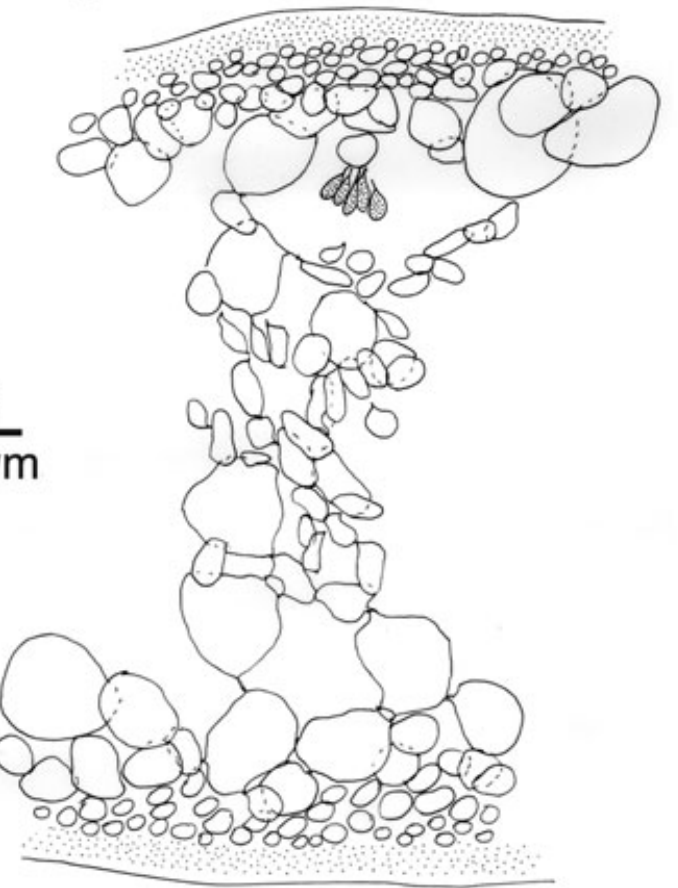

4

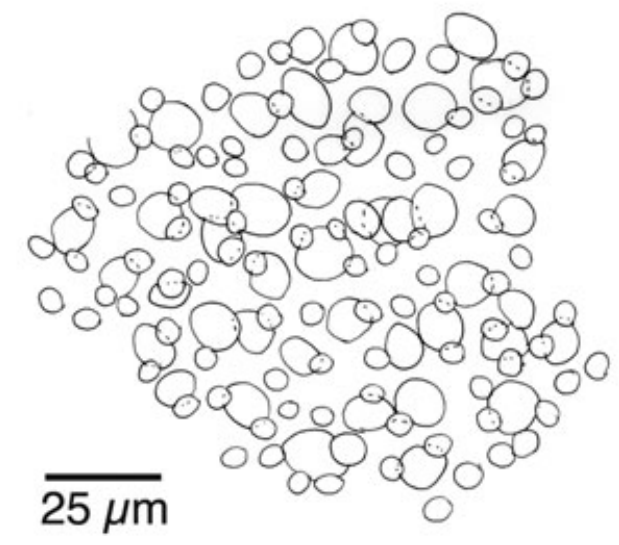

5

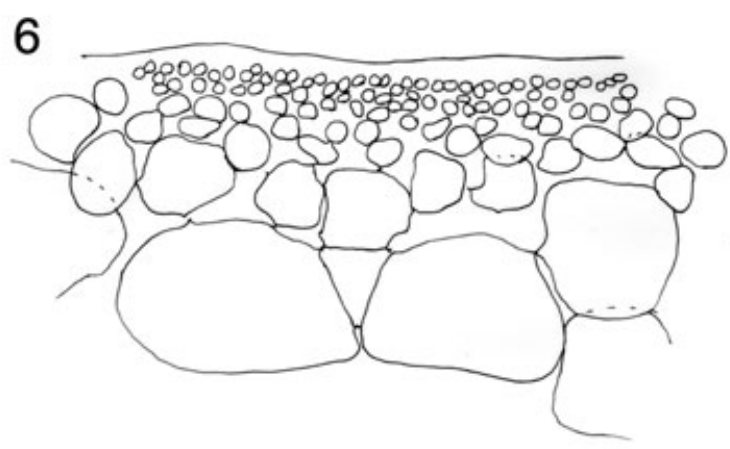

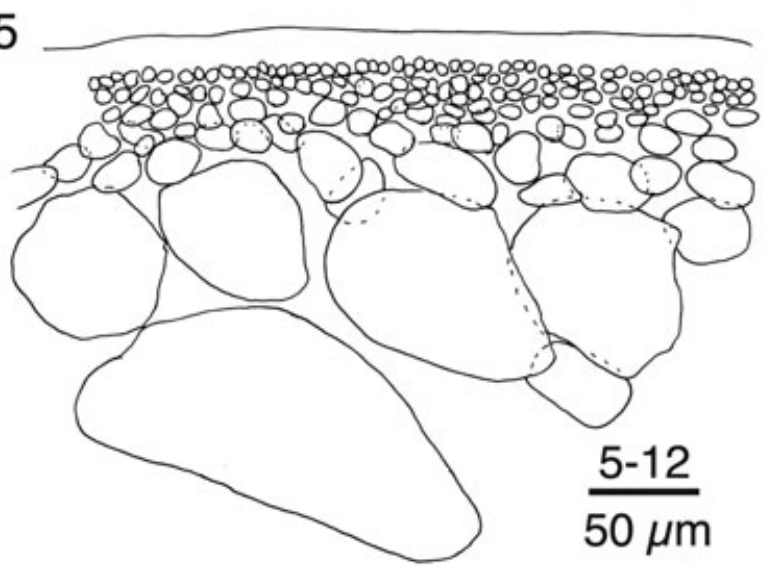

7
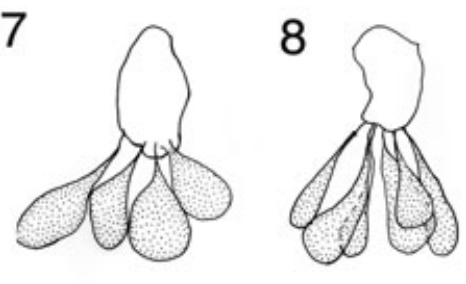

9
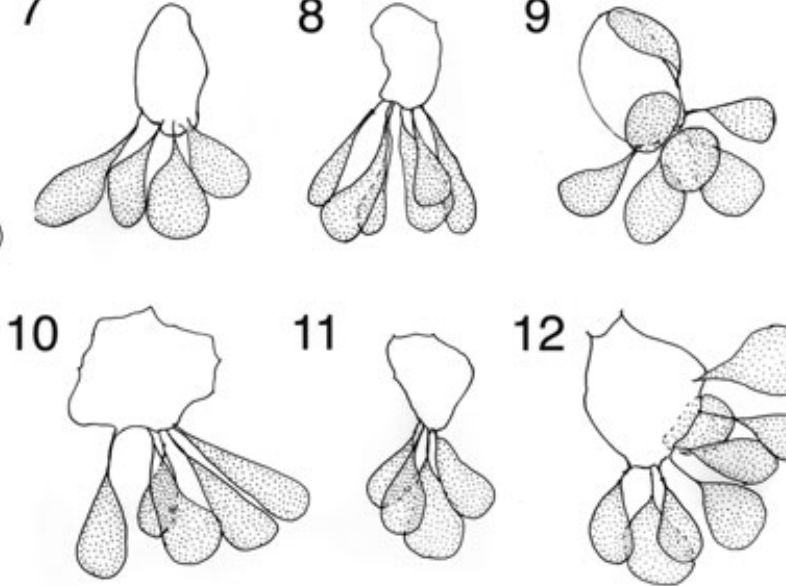

11

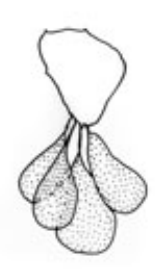

12

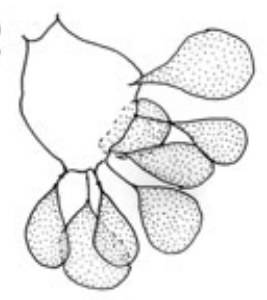

Figs 2-12. Chrysymenia tigillis. 2,3. Medullary struts between insides of surface layers. 4. Surface view of cortex. 5,6. Crosssections of blade, showing portion of cortex, subcortex, and medullary cells. 7-12. Examples of gland cell arrangements. 
has a continuous layer of surface cells (Fig. 4) and is made up of 3-5 layers of small pigmented cells in depth (Figs 5,6). The edges of the blade are much more thickened, comprised of a dozen or more layers of cortical cells. The cells of the cortex are subtended by larger subcortical cells and then by even larger medullary cells, $145-178 \mu \mathrm{m} \times 62-132 \mu \mathrm{m}$ in size. The subcortex is composed of a mixture of smaller cells and larger cells. The subcortical and medullary cells are 23 cell layers in total (Figs 5,6). Gland cells are common and are borne on innermost medullary cells, facing into the central cavity. Gland cells are pyriform, 36-46 $\mu \mathrm{m}$ in length and 16-32 $\mu \mathrm{m}$ in diameter, darkly staining (with aniline blue). There are usually 5-8 gland cells per bearing cell (Figs 7-12), but occasionally only 2 or 3 gland cells are present per bearing cell. Usually the bearing cells are small, are often refractive, and, like the gland cells, stain densely with aniline blue. Rarely, the gland cells are located on larger bearing cells, but they do not absorb aniline blue stain intensely and are not refractive.

\section{Reproductive structures}

Female thalli bear abundant cystocarps, scattered randomly over both blade surfaces. At maturity, the peri- carps are hemispherical, protruding from the blade surface, ostiolate, and the discrete carposporophytic mass is $360-545 \mu \mathrm{m}$ in diameter. Male and tetrasporangiate thalli were not seen.

\section{Chrysymenia planifrons (Figs 13-19)}

Because the species C. planifrons is not a well-known species and because of its similarity to the new species being described from the Sultanate of Oman, it is appropriate to include some observations on specimens of the former species. It is the only species of Chrysymenia which comes close to $C$. tigillis in its overall dimensions (height and width). Specimens of C. planifrons on loan from NY were essentially large simple blades. One of the pressed specimens (Fig. 13) measured about $31 \mathrm{~cm}$ in length and $25 \mathrm{~cm}$ in width (it was much folded over, and so its actual width was certainly greater). The second specimen (Fig. 14) was $32 \mathrm{~cm}$ in length and approximately $19 \mathrm{~cm}$ in width. Both specimens bore abundant scattered cystocarps, but the blade surface was smooth compared to the very rough surface of $C$. tigillis. Cross-sections of this material revealed a cortex that consisted of fewer layers of cells than that of C. tigillis. The cortical cells in the surface layer of
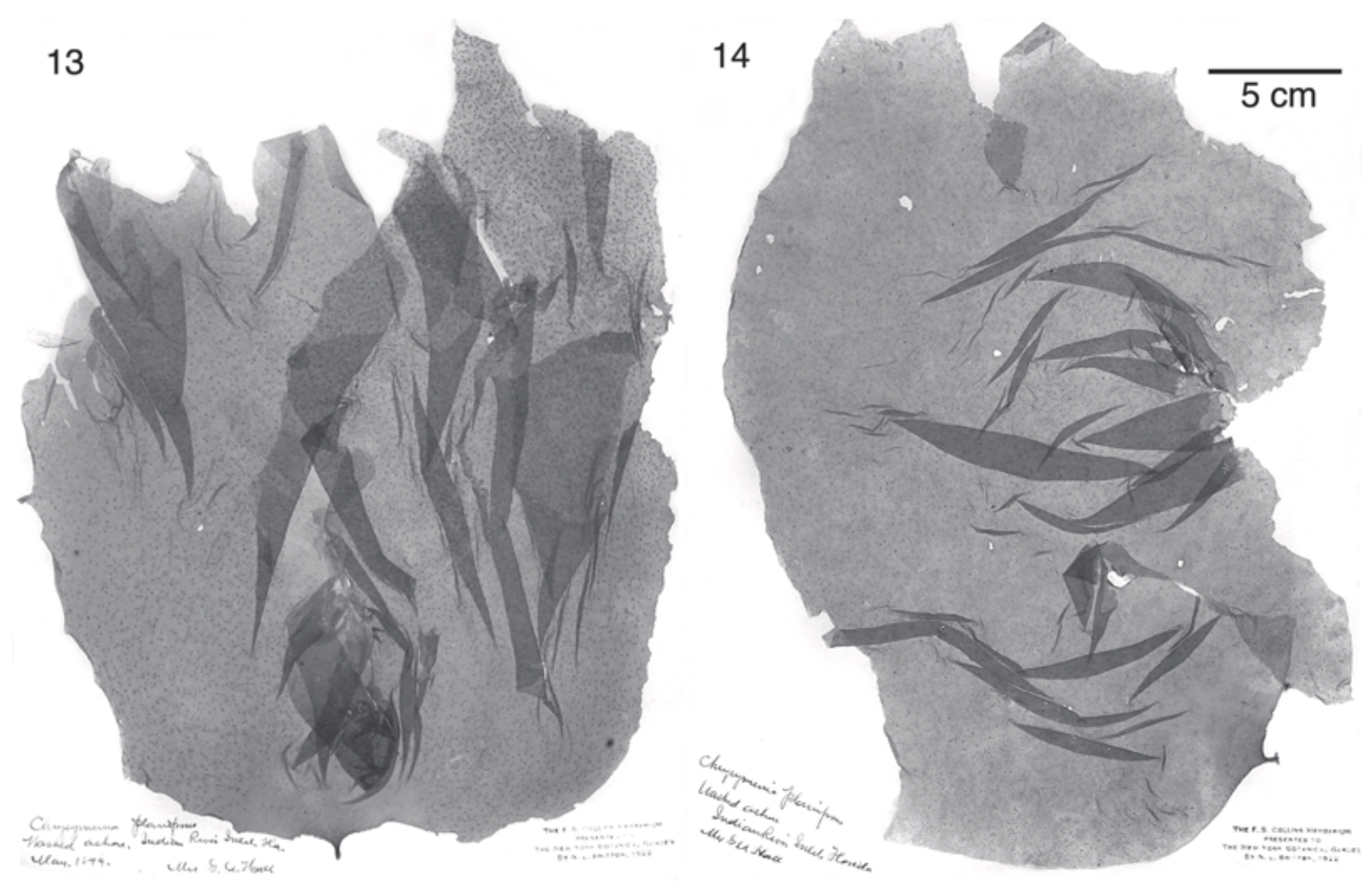

Figs 13,14 . Chrysymenia planifrons, specimens from Indian River Inlet, Florida (NY). 

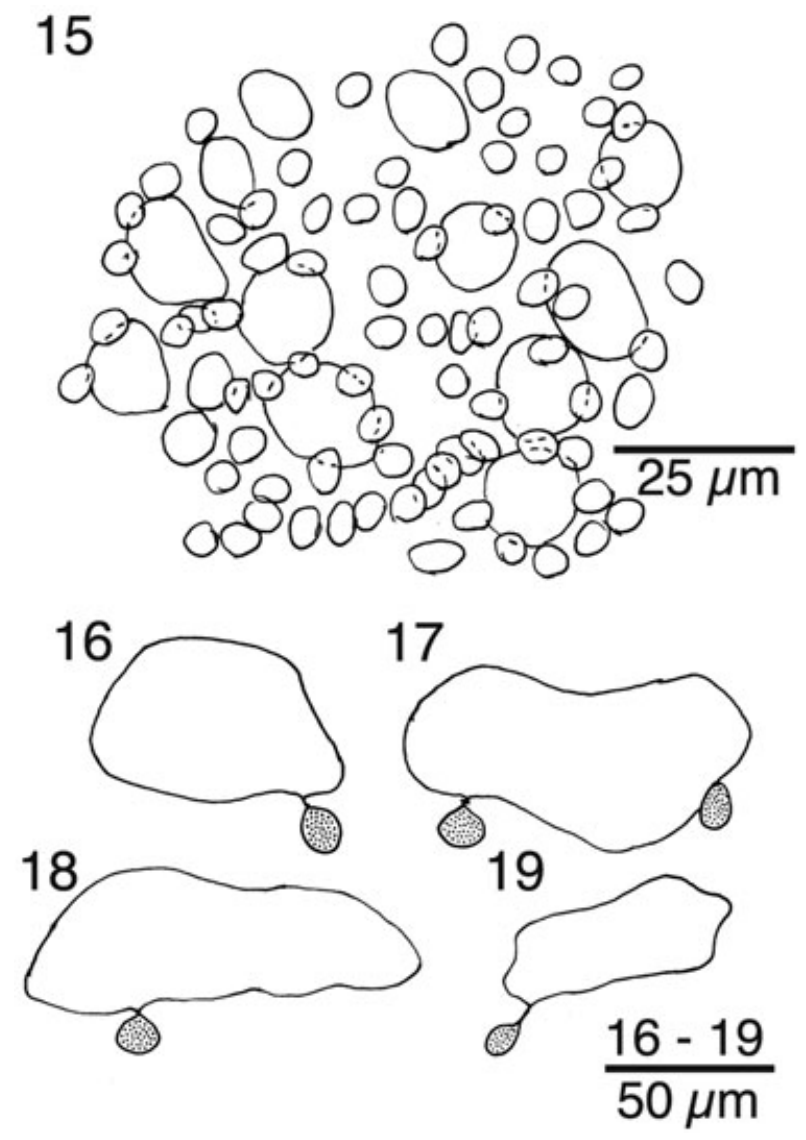

Figs 15-19. Chrysymenia planifrons. 15. Surface view of cortex. 16-19. Examples of gland cell arrangements.

C. planifrons (Fig. 15) were more dispersed than seen in $C$. tigillis, and they were underlain by larger subcortical cells. Gland cells were observed in C. planifrons, but they tended to occur singly or in pairs from the bearing cells (Figs 16-19).

In NY is a photograph of an isotype specimen of 'Chrysymenia Agardhii planifrons Melvill' in the Agardh Herbarium (LD), with notes indicating that there were three such 'co-types' from Key West, Florida, in LD. One specimen was said to be 'with conspicuous cystocarps'. The single photograph was of no. 26451 (LD), said to be the 'largest, though sterile'. It depicts a blade broader than long, deeply lobed, with a proliferous margin.

Another species of the genus also described from Florida was Chrysymenia curtissiana J. Agardh (1885), which Kylin (1931) treated as a taxonomic synonym of $C$. planifrons, saying that it was merely a large form of C. planifrons. According to Kylin (1931) a single specimen of $C$. curtissiana in the Agardh Herbarium (LD) was $42 \mathrm{~cm}$ long and $25 \mathrm{~cm}$ broad, with the upper part of the thallus divided into some large, broad lobes.

\section{DISCUSSION}

Chrysymenia J. Agardh (1842), based on the type species Chrysymenia ventricosa (J. V. Lamour.) J. Agardh, is assigned to the family Rhodymeniaceae (order Rhodymeniales) (Saunders et al. 1999). Currently, most workers in the Rhodymeniaceae treat Cryptarachne (Harvey) Kylin as congeneric with Chrysymenia. Harvey's (1853) subgenus Cryptarachne was raised to generic rank by Kylin (1931) on the basis of the presence of internal rhizoids filling the hollow center in species assigned to Cryptarachne and their alleged absence in Chrysymenia sensu stricto. Børgesen (1910), however, observed that although in young parts of the thalli of $C$. ventricosa rhizoidal filaments were absent, they appeared in mid portions of the thalli and 'occurred richly' in lower (older) portions. These observations, therefore, cast doubt on the reliability of this feature to distinguish Chrysymenia and Cryptarachne. Okamura (1936) chose not to recognize Cryptarachne as distinct from Chrysymenia, and this taxonomic opinion was followed by Yamada and Segawa (1953), Abbott and Littler (1969), Silva et al. (1996), and Saunders et al. (1999). Yet other workers have maintained Cryptarachne as distinct, such as Taylor (1960), Yoshida (1998), and Xia and Zhang (1999). Xia and Zhang (1999) recognized Cryptarachne kairnbachii (Grunow) Kylin, Cryptarachne okamurae (Yamada et Segawa) Zhang et Xia (1983); and Cryptarachne reticulate Xia et Wang, a name that appears to be a nomen nudum.

In the present study, Cryptarachne is treated as congeneric with Chrysymenia and, therefore, Chrysymenia polyglandulosa Okamura (1930) is retained within Chrysymenia. If Cryptarachne were to be maintained, Chrysymenia would then be reduced to approximately a dozen species. Therefore, a total of 20 species are here recognized as being assigned to Chrysymenia (Appendix 1). The species of Chrysymenia were assigned to three artificial divisions, or morphological 'form-groups', by Norris and Ballantine (1995). The first form-group, including C. ventricosa, C. halymenioides, C. enteromorpha, C. vesiculosa, C. wrightii, and C. grandis, have erect thalli that are terete to moderately compressed. The second form-group, including C. agardhii, C. planifrons, C. dickieana, C. lobata, C. polyglandulosa, and C. ornata, have erect thalli that are flattened and blade-like. The final group were those species with repent thalli with flattened or lobed forms; this group included C. kaernbachii, C. procumbens, C. okamurae, and C. glebosa. Norris and Ballantine (1995) assigned their two newly described species, C. littleriana and C. nodulosa, to the first form-group because of their thalli being slightly too moderately compressed throughout. Two other species, C.? polydactyla Hooker 
Table 1. Comparison of selected species of Chrysymenia

\begin{tabular}{|c|c|c|c|c|c|}
\hline & $\begin{array}{l}\text { Chrysymenia } \\
\text { agardhii }\end{array}$ & $\begin{array}{l}\text { Chrysymenia } \\
\text { polyglandulosa }\end{array}$ & $\begin{array}{l}\text { Chrysymenia } \\
\text { ornata }\end{array}$ & $\begin{array}{l}\text { Chrysymenia } \\
\text { planifrons }\end{array}$ & $\begin{array}{l}\text { Chrysymenia } \\
\text { tigillis }\end{array}$ \\
\hline Habitat/depth & $24-32 \mathrm{~m}$ & - & $10-13 \mathrm{~m}$ & $30 \mathrm{~m}$ & $8 \mathrm{~m}$ \\
\hline Height $(\mathrm{cm})$ & $10-20$ & 9 & 20 & to 40 & to 75 \\
\hline Width $(\mathrm{cm})$ & $\begin{array}{l}1-5 ; \\
\text { segments 2.0-2.5 }\end{array}$ & $\begin{array}{l}5-10 \text { overall, but narrow } \\
\text { segments }\end{array}$ & $3-5$ & 25 & $9-21$ \\
\hline Thickness (mm) & $0.7-1.1$ & - & $1 \mathrm{~mm}$ & - & $-1 \mathrm{~mm}$ \\
\hline Branching pattern & Simple,forked & $\begin{array}{l}\text { Irregularly dichotomous, } \\
\text { deeply lobed }\end{array}$ & $\begin{array}{l}\text { irregularly deeply } \\
\text { cleft or lobed }\end{array}$ & $\begin{array}{l}\text { simple, with } \\
\text { deltoid lobes }\end{array}$ & simple \\
\hline No. cortical layers & $2-3$ & $1-2$ & $1-2$ & 1 & $3-5$ \\
\hline $\begin{array}{l}\text { No. subcortex/ } \\
\text { medullary layers }\end{array}$ & $1-2$ & $2-4$ & $1-2$ & $1-2$ & $2-3$ \\
\hline $\begin{array}{l}\text { No. gland cells } \\
\text { per bearing cell }\end{array}$ & $2-4$ & Present & 1-several & $1-$ few & $5-8$ \\
\hline Hollow & $\begin{array}{l}\text { Yes, mucilage } \\
\text { filled }\end{array}$ & Yes & $\begin{array}{l}\text { Yes; } \\
\text { gelatinous }\end{array}$ & $\begin{array}{l}\text { More or less } \\
\text { hollow }\end{array}$ & $\begin{array}{l}\text { Yes; mucilage } \\
\text { filled }\end{array}$ \\
\hline $\begin{array}{l}\text { Presence of } \\
\text { medullary } \\
\text { filaments }\end{array}$ & $\begin{array}{l}\text { A dense plexus; } \\
\text { numerous; } \\
\text { few-several }\end{array}$ & $\begin{array}{l}\text { Few oblong medullary } \\
\text { cells }\end{array}$ & $\begin{array}{l}\text { None, but rarely } \\
\text { inner cortical } \\
\text { cells contiguous }\end{array}$ & $\begin{array}{l}\text { 'Lacking'; 'some } \\
\text { hyphae' }\end{array}$ & $\begin{array}{l}\text { Transverse 'struts' } \\
\text { betweeen inner } \\
\text { surfaces }\end{array}$ \\
\hline $\begin{array}{l}\text { Female thalli; } \\
\text { cystocarps }\end{array}$ & $\begin{array}{l}\text { Scattered over } \\
\text { surface }\end{array}$ & Scattered over surface & - & $\begin{array}{l}\text { Scattered over } \\
\text { surface }\end{array}$ & $\begin{array}{l}\text { Scattered over } \\
\text { surface }\end{array}$ \\
\hline $\begin{array}{l}\text { Size of } \\
\text { tetrasporangia }\end{array}$ & Approximately $27 \mu \mathrm{m}$ & - & $25 \mu \mathrm{m} \times 18 \mu \mathrm{m}$ & - & - \\
\hline $\begin{array}{l}\text { Type locality; } \\
\text { distribution }\end{array}$ & $\begin{array}{l}\text { Key West, FL, USA; } \\
\text { North Carolina, } \\
\text { Caribbean, Bermuda }\end{array}$ & $\begin{array}{l}\text { Yoshikawa, Hatidyo } \\
\text { I., } 7 \text { Islands of Idzu, } \\
\text { Japan }\end{array}$ & $\begin{array}{l}\text { Port Jackson, NSW; } \\
\text { eastern Australia } \\
\text { and New Zealand }\end{array}$ & $\begin{array}{l}\text { Key West, FL, } \\
\text { USA; Virgin } \\
\text { Islands, Netherland } \\
\text { Antilles, Bermuda? }\end{array}$ & Sadh, Oman \\
\hline References $\dagger$ & $1,2,3,4,5$ & 9 & $4,6,7$ & $1,2,4,8,10$ & 10 \\
\hline
\end{tabular}

†(1) Børgesen (1910); (2) Børgesen (1920); (3) Harvey (1853); (4) Kylin (1931); (5) Taylor (1928); (6) Agardh 1885); (7) Millar (1990); (8) Taylor (1960); (9) Okamura (1930); (10) the present paper. -, no data.

f. et Harvey and C. coelarthroides Feldm.-Maz., would appear to belong to the first form group. According to Adams (1994), however, the generic assignment of the former species remains uncertain.

The new species of Chrysymenia from Oman, with its broadly foliose thalli, clearly belongs to the second form-group, and so a comparison will be restricted to those species with erect and flattened forms. C. ornata, reported from eastern Australia (Agardh 1885), New Zealand (Adams 1994), and Norfolk Island (Millar 1999), has been shown by Kylin (1931) and Millar (1990) to have a foliose thallus, to be deeply and irregularly divided and with many marginal blades. Harvey (1863, as Halosaccion digitatum) depicted it as dichotomously branched. The much divided habit of C. ornata separates it from the Omani alga under discussion. Further comparison will be made with three other species assigned to form-group 2 (Table 1). Interestingly, if Cryptarachne were to be recognized as distinct, three of these four species being compared (C. agardhii, C. planifrons, and C. polyglandulosa) have all been placed in Cryptarachne.
Chrysymenia agardhii has flat, undulate thalli, cuneate at the base, expanding into dichotomously to palmately laciniate distal lobes, to $2.5 \mathrm{~cm}$ broad (Harvey 1853; Taylor 1960). Margins of the blades are irregularly erose-dentate, and the medulla is densely packed with numerous rhizoidal filaments (Harvey 1853). C. dickieana is eliminated from further consideration in that thalli in that species consist of much branched, flattened axes, but the branches reach up to only $5 \mathrm{~mm}$ in width (Taylor 1960). Kylin (1931; pl. 3, fig. 7) has depicted the type specimen of $C$. dickieana.

The habit of $C$. planifrons most approximates that of the Omani species in being erect, broadly foliose, The distribution of $C$. planifrons includes the east coast of Florida, extending southward to Key West (the type locality), and the West Indies (Børgesen 1920; Taylor 1960). Schneider (2003) queried its occurrence in Bermuda. Taylor (1942) later corrected his earlier report (Taylor 1930) of C. planifrons from Cabo Frio, Brazil, describing the Brazilian material as the new species Fauchea peltata W. R. Taylor, now known as Asteromenia peltata (W. R. Taylor) Huisman and Millar (1996). 
Chrysymenia grandis has been described as 'large, tubular, elongated, filled with jelly', shortly stipitate at the base (Okamura 1933). Okamura characterized the thalli to be simple, oblong or ovate when young and later become branched into a few segments, whereas Kajimura (1998) observed thalli from the Oki Islands to be terete, unsegmented, entirely hollow, mostly simple, reaching $25 \mathrm{~cm}$ in height and with a diameter of $5 \mathrm{~cm}$. A pressed specimen of $C$. grandis in $\mathrm{MICH}$ (from the Oki Islands, Japan) has a broadly foliose aspect with a single erect habit $(16 \mathrm{~cm}$ in length by $6.5 \mathrm{~cm}$ in width). Both Okamura (1933) and Kajimura (1998) were in agreement that the thalli in this species have a cylindrical or terete form, and it is when pressed that the specimens give the false impression of being foliose. Therefore, $C$. grandis can be eliminated from consideration.

\section{ACKNOWLEDGMENTS}

I wish to acknowledge the Algal Biodiversity Project of Oman (1999-2002), funded by a British Government's Darwin Initiative grant for the 'Survival of Species'. The project was managed by HTS Development, UK, working with the Natural History Museum of Muscat, Oman, and supported by the Natural History Museum of London and the Herbarium of the University of Michigan. The Darwin Initiative is part of the British Government's Department of Environment Transport and the Regions (DETR). I am grateful to the following individuals for their contributions to this research: Dr Lynne Barratt, Mr Glenn Richards, and Ms Emma Dodsworth, all of whom were personnel of HTS Development, and to Mr Henry Ford, Mrs Gianna Minton, and Mr Tim Collins for their participation on the collecting trips. I thank Ms Ellen Bloch of The New York Botanical Gardens Herbarium for a loan of material. I thank Dr Alan Millar and an anonymous reviewer for their constructive comments. I am grateful to Mr David Bay for his photographic skills.

\section{REFERENCES}

Abbott, I. A. and Littler, M. M. 1969. Some Rhodymeniales from Hawaii. Phycologia 8: 165-9.

Adams, N. M. 1994. Seaweeds of New Zealand. An Illustrated Guide. Canterbury University Press, Christchurch, 360 pp.

Agardh, J. G. 1842. Algae Maris Mediterranei et Adriatici, Observations in Diagnosin Specierum et Dispositionem Generum. Fortin, Masson et Cie, Paris, $x+164$ pp.

Agardh, J. G. 1851. Species Genera et Ordines Algarum, Vol. II, Part 1. C. W. K. Gleerup, Lundae (Lund), xii + 351 pp.

Agardh, J. G. 1876. Species Genera et Ordines Algarum ... Epicrisis Systematis Floridearum, Vol. III, Part 1. T. 0. Weigel, Lipsiae (Leipzig), viii + 724 pp.
Agardh, J. G. 1885. Till algernes systematik. Nya bidrag. VII. Florideae. Lunds Univ. Årsskr. 21 (8): $117+$ [3] pp., 1 pl.

Agardh, J. G. 1892. Analecta algologica. Observationes de speciebus minus cognitis earumque dispositione. Lunds Univ. Årrkk. 28 (6): 1-182, pls. 1-3.

Børgesen, F. 1910. Some new or little known West Indian Florideae. II. Bot. Tidssrift 30: 177-206.

Børgesen, F. 1920. The marine algae of the Danish West Indies. Part III. Rhodophyceae 6. Dansk Bot. Ark. 3: 369498.

Brodie. J. and Guiry, M. D. 1988. Life history and reproduction of Botryocladia ardreana sp. nov. (Rhodymeniales, Rhodophyta) from Portugal. Phycologia 27: 109-30.

Feldmann, G. 1945. Révision du genre Botryocladia Kylin (Rhodophycées-Rhodyméniacées). Bull. Soc. Hist. Nat. Afr. Nord 35: 49-61.

Feldmann-Mazoyer, G. 1941. Une nouvelle espèce de Chrysymenia des côtes Nord-Africaines. Bull. Soc. Hist. Nat. Afr. Nord 32: 296-300.

Harvey, W. H. 1853. Nereis boreali-americana. Part II. Rhodospermeae. Smithsonian Contributions Knowledge 5 (2): 258, pls. XIII-XXXVI.

Harvey, W. H. 1855. Algae. In Hooker, J. D. (Ed.) The Botany of the Antarctic Voyage of H.M. Discovery Ships Erebus and Terror in the Years 1839-1843. II. Flora NovaeZelandiae. Part II. Flowerless plants. Reeve, London, pp. 211-66, pls, 107-21.

Harvey, W. H. 1860a. ('1859'). Characters of new algae, chiefly from Japan and adjacent regions, collected by Charles Wright in the North Pacific Exploring Expedition under Captain Charles John Rodgers. Proc. Am. Acad. Arts Sci. 4: 327-35.

Harvey, W. H. 1860b. Phycologia Australica. Reeve, London, Vol. III. PIs. 121-80.

Harvey, W. H. 1863. Phycologia Australica. Reeve, London, Vol. V. PIs. 241-300.

Hauck, F. 1883. Die Meeresalgen Deutschlands und Oesterreichs. In Rabenhorst, L. (Ed.) Kryptogamen-Flora von Deutschland, Oesterreich und der Schweiz. Zweite Auflage, Leipzig, pp. 113-320.

Holmgren, P. K., Holmgren, N. H. and Barnett, L. C. 1990. Index Herbariorum, Part I. The Herbaria of the World. New York Botanical Garden, Bronx, NY. (Regnum Vegetabile vol. 120). X+693 pp.

Howe, M. A. 1914. The marine algae of Peru. Mem Torrey Bot. Club 15: 1-185, 66 pls.

Huisman, J. M. and Millar, A. J. K. 1996. Asteromenia (Rhodymeniaceae, Rhodymeniales), a new red algal genus based on Fauchea peltata. J. Phycol. 32: 138-45.

Kajimura, M. 1998. The morphology of Chrysymenia grandis (Rhodymeniaceae, Rhodophyta) from the Oki islands. Studies of the San'in Region (Natural Environment). Research Center for Coastal Lagoon Environmenta. Shiman University, Japan. No. 14, 6 pp.

Kylin, H. 1931. Die Florideenordnung Rhodymeniales. Lunds Univ. Arsskr. N.F., Avd. 2, 27 (11): 48 pp, 20 pls. 
Kylin, H. 1956. Die Gattungen der Rhodophyceen. Gleerups, Lund. $x v+673 p p$.

Lamouroux, J. V. F. 1813. Essai sur les genres de la famille des Thalassiophytes non articulées. Annales Muséum Hist. Naturelle (Paris) 20: 21-47,115-39,267-93, pls 7-13.

Melvill, J. C. 1875. Notes on the marine algae of South Carolina and Florida. J. Bot. (London) 13: 258-65.

Millar, A. J. K. 1990. Marine red algae of the Coffs Harbour region, northern New South Wales. Austr. Syst. Bot. 3: 293-593.

Millar, A. J. K. 1999. Marine benthic algae of Norfolk Island, South Pacific. Austr. Syst. Bot. 12: 479-547.

Nizamuddin, M. and Campbell, A. C. 1995. Glossophorella, a new genus of the family Dictyotaceae (DictyotalesPhaeophyta) and its ecology from the coast of the Sultanate of Oman. Pak. J. Bot. 27: 257-62.

Norris, J. N. and Ballantine, D. L. 1995. Two new species of the red alga Chrysymenia J. Agardh (Rhodymeniales: Rhodymeniaceae) from the tropical Western Atlantic. Proc. Biol. Soc. Wash. 108: 153-65.

Okamura, K. 1930. On the algae from the Island Hatidyo. Records Oceanogr. Works Japan 2: 92-110.

Okamura, K. 1932. Icones of Japanese Algae. Self published, Tokyo. Vol. 6 pls. 286-290.

Okamura, K. 1933. Icones of Japanese Algae. Self published, Tokyo. Vol. 7 pls. 301-305.

Okamura, K. 1936. Nippon Kaiso Shi (Descriptions of Japanese algae). Uchida Rokakuho Publishing House, Tokyo. $9+6+964+11$ pp. (In Japanese.)

Ricker, R. W. and Kraft, G. T. 1979. Morphology of the subantarctic red alga Cenacrum subsutum gen. et sp. nov. (Rhodymeniales) from Macquarie Island. J. Phycol. 15: 434-44.

Saunders, G. W., Strachan, I. M. and Kraft, G. T. 1999. The families of the order Rhodymeniales (Rhodophyta): a molecular-systematic investigation with a description of Faucheaceae fam. nov. Phycologia 38: 23-40.

Schils, T. and Coppejans, E. 2002. Gelatinous red algae of the Arabian Sea, including Platoma heteromorphum sp. nov. (Gigartinales, Rhodophyta). Phycologia 41: 254-67.

Schneider, C. W. 2003. An annotated checklist and bibliography of the marine macroalgae of the Bermuda Islands. Nova Hedwigia 76: 275-361.

Schumann, K. and Hollrung, M. 1889. Die Flora von Kaiser Wilhelmsland. Asher \& Co., Berlin. v + 137 pp.

Segawa, S. 1949. Five Floridean genera new to Japan. J. Jpn. Bot. 24: 159-65.

Silva, P. C., Basson, P. W. and Moe, R. L. 1996. Catalogue of the benthic marine algae of the Indian Ocean. Univ. Calif. Publ. Bot. 79: xiv +1259 pp.

Sparling, S. R. 1957. The structure and reproduction of some members of the Rhodymeniaceae. Univ. Calif. Publ. Bot. 29: 319-96.

Taylor, W. R. 1928. The marine algae of Florida with special reference to the Dry Tortugas. Carnegie Institution Washington, Washington DC, Publication 379, V + 220 pp, 37 pls.
Taylor, W. R. 1930. Algae collected by the Hassler, Albatross, and Schmitt expeditions. I. Marine algae from Brazil. Am. J. Bot. 17: 627-34.

Taylor, W. R. 1942. Caribbean marine algae of the Allan Hancock Expedition, 1939. Allan Hancock Atlantic Expedition, Report no. 2. The University of Southern California Press, Los Angeles, CA, 193 pp.

Taylor, W. R. 1960. Marine Algae of the Eastern Tropical and Subtropical Coasts of the Americas. University of Michigan Press, Ann Arbor, MI, ix +870 pp.

Weber-van Bosse, A. 1928. Liste des algues du Siboga, IV. IV. Rhodophyceae: Gigartinales et Rhodymeniales. SibogaExpeditie Monographie E. J. Brill, Leiden. 393-533, pls. 11-16.

Womersley, H. B. S. 1996. The marine benthic flora of southern Australia. Part IIIB Gracilariales, Rhodymeniales, Corallinales and Bonnemaisoniales. Australian Biological Resources Study, Canberra. 392 pp.

Wynne, M. J. 1998. Champia gigantea and Lomentaria strumosa (Rhodymeniales): two new red algae from the Sultanate of Oman. Bot. Mar. 41: 571-80.

Wynne, M. J. 1999a. Pseudogrinnellia barrattiae gen. et sp. nov., a new member of the red algal family Delesseriaceae from the Sultanate of Oman. Bot. Mar. 42: 37-42.

Wynne, M. J. 1999b. New records of benthic marine algae from the Sultanate of Oman. Contr. Univ. Mich. Herb. 22: 189-208.

Wynne, M. J. 2000. Further connections between the benthic marine algal floras of the northern Arabian Sea and Japan. Phycol. Res. 48: 211-20.

Wynne, M. J. 2001a. New records of benthic marine algae from the Sultanate of Oman, northern Arabian Sea. II. Nova Hedwigia 72: 347-74.

Wynne, M. J. 2001b. New records of benthic marine algae from the Sultanate of Oman, northern Arabian Sea. III. Cont. Univ. Mich. Herb. 23: 389-406.

Wynne, M. J. 2002a. A description of Plocamium fimbriatum sp. nov. (Plocamiales, Rhodophyta) from the Sultanate of Oman, with a census of currently recognized species in the genus. Nova Hedwigia 73: 333-56.

Wynne, M. J. 2002b. Turbinaria foliosa sp. nov. (Fucales, Phaeophyceae) from the Sultanate of Oman, with a census of currently recognized species in the genus Turbinaria. Phycol. Res. 50: 283-93.

Wynne, M. J. 2003a. Jolyna furcata sp. nov. (Scytosiphonales, Phaeophyceae) from the Sultanate of Oman. Cryptogamie, Algol. 24: 51-61.

Wynne, M. J. 2003b. Leveillea major sp. nov. (Rhodomelaceae, Rhodophyta) from the Sultanate of Oman. Bot. Mar. 46: 357-65.

Wynne, M. J. 2003c. Centroceras secundum sp. nov. (Ceramiaceae, Rhodophyta) from the Sultanate of Oman. Nova Hedwigia 77: 125-37.

Wynne, M. J. 2004. Myriogloea pedicellata sp. nov. (Chordariaceae, Phaeophyceae) from the Sultanate of Oman, northern Arabian Sea. Cryptogamie, Algol. 25: 113-24. 
Wynne, M. J. 2005. Two new species of Bryopsis (Ulvophyceae, Chlorophyta) from the Sultanate of Oman, with a census of currently recognized species in the genus. Contr. Univ. Mich. Herb. 24: 229-56.

Wynne, M. J. and Jupp, B. P. 1998. The benthic marine algal flora of the Sultanate of Oman: new records. Bot. Mar. 41: 7-14.

Wynne, M. J. and Leliaert, F. 2001. Pedobesia simplex (Kützing) comb. nov. (Chlorophyta), a new name for $P$. lamourouxii and its first report from the Indian Ocean. Cryptogamie, Algol. 22: 3-14.

Wynne, M. J. and de Jong, Y. S. D. M. 2002. Dipterocladia arabiensis sp. nov. (Dasyaceae, Rhodophyta) from the Sultanate of Oman. Bot. Mar. 45: 77-86.

Wynne, M. J. and Freshwater, D. W. 2004. Gelidium omanense sp. nov. (Gelidiaceae, Rhodophyta) from the Sultanate of Oman. Bot. Mar. 47: 64-72.

Xia, B., and Zhang, J. (Eds) 1999. Flora Algarum Marinarum Sinicarum Tomus /I Rhodophyta, No. V. Ahnfeltiales, Gigartinales, Rhodymeniales. Consilio Florarum Cryptogamarum Sinicarum, Academiae Sinicae Edita. Science Press, Beijing. vi +201 pp, 11 pls. (In Chinese; keys in English.)

Yamada, Y. 1932. Notes on some Japanese algae. III. J. Fac. Sci., Hokkaido Imp. Univ., Ser. V, 1: 109-23, pls 21-25.

Yamada, Y. and S. Segawa. 1953. On some new or noteworthy algae from Hachijo Island. Records Oceanogr. Works Japan 1: 100-14.

Yoshida, T. 1998. Marine Algae of Japan. Uchida Rokakuho Publishing, Tokyo. 1222 pp. (In Japanese.)

Zanardini, G. 1863. ('1862'). Scelta di Ficee nuove o piú rare del mare Adriatico. Mem. R. Ist. Veneto Sci., Lett. Arti 11: 269-306, plates XXV-XXXII.

Zhang, J. and Xia, B. 1983. Studies on some marine red algae of the Xisha Islands, Guangdong Province, China. IV. Studia Marina Sinica 20: 123-40.

\section{APPENDIX 1}

\section{Currently recognized species of Chrysymenia:}

1. C. agardhii Harvey (1853): 189, pl. XXX, fig. A (type locality: Key West, Florida, USA).

2. C. coelarthroides Feldm.-Maz. (1941): 299, figs 1-3 (type locality: near Bougie (anc. Saldae), Algeria, Mediterranean Sea).

3. C. dickieana J. Agardh (1892): 90 (type locality: Bahia, Brazil).

4. C. enteromorpha Harvey (1853): 187-188. (type locality: Key West, Florida, USA).

5. C. glebosa Abbott and Littler (1969): 167, fig. 3 (type locality: War Memorial Natatorium, Waikiki, Honolulu, Hawaii, USA).

6. C. grandis Okamura (1933): 1, pl. 301 (type locality: deep waters, Tateyama Bay, Japan).
7. C. halymenioides Harvey (1853): 188, pl. XX, fig. A (type locality: Key West, Florida, USA).

8. C. kaernbachii Grunow in Schumann and Hollrung (1889): 4 (type locality: Kelana, Papua New Guinea).

9. C. littleriana Norris and Ballantine (1995): 154, figs 1a,1b,6,10-14 (type locality: Diamond Rock, Martinique, French West Indies, Lesser Antilles).

10. C. (?) lobata Howe (1914): 129, fig. 41, pl. 53 (type locality: 9 fathoms, Ancón Bay, Peru).

11. C. nodulosa Norris and Ballantine (1995): 159, figs 2a,b, 4,5,7,8a,b and 9 (type locality: Media Luna Reef, La Parguera, Puerto Rico, Greater Antilles).

12. C. okamurae Yamada and Segawa (1953): 110, fig. 3, as 'okamurai': (syntype localities: Sokodo and Borawazawa, Hachijo Island, off SE Honshu, Japan); C. kaernbachii sensu Okamura (1932; pl. 288, figs $1-8$ ).

13. C. ornata (J. Agardh) Kylin (1931): 10, pl. 3, fig. 6; basionym: Callophyllis ornata J. Agardh (1885): 35 (type locality: Port Jackson, New South Wales, Australia); taxonomic synonym C.? digitata (Harvey) J. Agardh (1876): 323 nom. illeg.; basionym: Gloiosaccion? digitatum Harvey (1863): pl. 259 (type locality: in deep water, Port Jackson, New South Wales, Australia). J. Agardh's name is a later homonym of $C$. digitata Zanardini (1863), which has been regarded as a possible forma of (Hauck 1883) or conspecific with C. ventricosa (Kylin 1931). Millar (1999) proposed to treat C. digitata as conspecific with $C$. ornata.

14. C. planifrons (Melvill) J. Agardh (1876): 319; basionym: Chrysymenia agardhii (var.) planifrons Melvill (1875): 263 (type locality: Key West, Florida, USA); taxonomic synonym C. curtissiana J. Agardh (1885) fide Kylin (1931).

15. C.? polydactyla Hooker f. et Harvey in Harvey (1855): 253 (type locality: Port Pegasus, South Harbor, New Zealand).

16. C. polyglandulosa Okamura (1930): 96, pl. VI (type locality: Yoshikawa, Japan); Cryptarachne glandulosa (Okamura) Segawa (1949).

17. C. procumbens Weber-van Bosse (1928): 470, pl. V, fig. 2a,b (syntype localities: 'Banc de Borneo' and 'lle Tiur').

18. C. vesiculosa J. Agardh (1851): 213 (type locality: 'Tingin' $=$ Tangier, Morocco).

19. C. ventricosa (Lamouroux) J. Agardh (1842): 106; basionym: Dumontia ventricosa Lamouroux (1813): 45, pl. 10, fig. 6 (type locality: French Mediterranean).

20. C. wrightii (Harvey) Yamada (1932): 118, fig. 4; pl. XX; basionym: Halosaccion wrightii Harvey (1860a): 332 (type locality: 'Hakodadi' = Hakodate, Japan). 
This document is a scanned copy of a printed document. No warranty is given about the accuracy of the copy. Users should refer to the original published version of the material. 